\title{
Testicular blood flow and testosterone concentrations in spermatic venous blood of anaesthetized rats
}

\author{
J.-E. Damber and P. O. Janson* \\ Department of Physiology, University of Umea, and \\ *Departments of Physiology and Obstetrics and Gynaecology, University of Göteborg, Sweden
}

\begin{abstract}
Summary. Testicular blood flow was measured by a radioactive microsphere technique. A significant correlation, $r_{\mathrm{s}}=\mathbf{0} \cdot \mathbf{8 2}$, was found between testicular blood flow and testosterone outflow in the spermatic venous blood, indicating that factors which affect the testicular circulation may influence testicular endocrine function.
\end{abstract}

\section{Introduction}

Many factors are known to affect testicular blood flow. Infusion of epinephrine or norepinephrine into the spermatic artery of rats (Free \& Jaffe, 1972a) or rams (Setchell, Waites \& Thorburn, 1966) leads to rapid vasoconstriction with a marked transient decrease in blood flow through the testis, and isoproterenol causes vasodilatation and increased blood flow in rams. Prostaglandins E-2 and F-2 $\alpha$ have been reported to decrease testicular blood flow in conscious rats (Free \& Jaffe, 1972b). Other agents which decrease testicular blood flow appear to be serotonin (Boccabella, Salgado \& Alger, 1961) and cadmium (Setchell \& Waites, 1970; Johnson \& Turner, 1972), but the role of these compounds in the normal function of the testis remains obscure.

Eik-Nes (1964), using an in-situ perfusion model of the testis, found a positive correlation between perfusion rate and secretion of testosterone in the dog. This finding and the observations that epinephrine (Levin, Lloyd, Lobotsky \& Friedrich, 1967) and prostaglandins (Saksena, Safoury \& Bartke, 1973) depress plasma testosterone levels suggest that these effects may be mediated through an influence on the testicular vascular bed.

The main purpose of the present study therefore was to study in vivo the relationship between testicular blood flow and the output of testosterone in the spermatic vein.

\section{Materials and Methods}

Male rats of the Sprague-Dawley strain (Møllegaard-Hansen, Ejby, Denmark), weighing $300-400 \mathrm{~g}$, were kept in a controlled environment (temperature: $25^{\circ} \mathrm{C}$, light 05:00-19:00 h). Standard rat pellets and water were always available. The anaesthetic used was sodium pentobarbitone (Nembutal: Abbott) given i.p. as a single dose of $40 \mathrm{mg} / \mathrm{kg}$. The animals were kept supine during each experiment, and body temperature was maintained by a heating pad.

\section{Measurement of testicular blood flow}

The use of radioactive microspheres has been shown to be suitable for testicular blood flow measurements in rats (Damber \& Janson, 1977). Radioactive 'carbonized' microspheres with a diameter of $15 \pm 5$ (range) $\mu \mathrm{m}$ were purchased from $3 \mathrm{M}$ Co. (St. Paul, Minnesota, U.S.A.). The microspheres were labelled with ytterbium-169 $\left({ }^{169} \mathrm{Yb}\right)$ or scandium- $46\left({ }^{46} \mathrm{Sc}\right)$. The initial specific activity of ${ }^{169} \mathrm{Yb}$ was $10.07 \mathrm{mCi} / \mathrm{g}$, and that of ${ }^{46} \mathrm{Sc}$ was $8.63 \mathrm{mCi} / \mathrm{g}$. Under anaesthesia catheters $(0.6 \mathrm{~mm}$ i.d., $1 \mathrm{~mm}$ o.d., PE-50: Intramedic, Clay Adams, U.S.A.) were inserted into the right brachial artery, the tail artery and into the left ventricle or the ascending aorta via the left carotid artery. The catheters were filled with a solution $(1: 10 \mathrm{v} / \mathrm{v})$ of heparin $(500$ i.u. $/ \mathrm{ml})$ and $0 \cdot 15 \mathrm{M}-\mathrm{NaCl}$. The brachial arterial 
catheter was connected to a Statham P23 AC transducer attached to a Grass Model 7 Polygraph. Approximately 50000 spheres, suspended in $20 \%(\mathrm{w} / \mathrm{v})$ dextran, were transferred to a glass chamber of a volume of $0.9 \mathrm{ml}$. The design of the chamber and the handling of it are described in detail by Rudolph \& Heymann (1967). The chamber containing the sphere suspension was vigorously agitated with a high-frequency mechanical stirrer and the suspension was flushed into the heart for $30 \mathrm{sec}$ with $1 \mathrm{ml} 0 \cdot 15 \mathrm{M}-\mathrm{NaCl}$. As reference samples, blood was withdrawn at a constant rate $(0 \cdot 8 \mathrm{ml} / \mathrm{min})$ from the tail artery catheter for $15 \mathrm{sec}$ before, during and after the infusion of microspheres.

Experiment 1. Seventeen rats were treated with a single infusion of microspheres $\left({ }^{169} \mathrm{Yb}\right.$ or $\left.{ }^{46} \mathrm{Sc}\right)$. Blood from the right spermatic vein was collected into pre-weighed glass tubes for $2 \frac{1}{2} \mathrm{~min}$ before and $2 \frac{1}{2} \mathrm{~min}$ after the start of the infusion. The right internal spermatic vein was cannulated at midline laparotomy with a PE-50 catheter inserted at least $5 \mathrm{~mm}$ from the point of entry into the caval vein. The catheter, 3-4 cm in length, was fixed so that the open end was at the level of the caval vein. The total blood volume collected during 5 min was calculated by dividing the difference in tube weight, before and after blood collection, with the specific weight of rat whole blood (1.05; J.-E. Damber, unpublished). The plasma volume was calculated from the haematocrit of rat blood $(45 \%$ J.-E. Damber, unpublished). The outflow of testosterone in the spermatic vein was calculated by multiplying the venous plasma flow with the plasma concentration of testosterone. After blood collection, the rats were killed by an overdose of sodium pentobarbitone and dissected. Radioactivities of the 'reference' samples and individual organs and tissues were measured in an automatic well scintillation counter (Packard Auto-Gamma). Each sample was counted for $3 \mathrm{~min}$. By counting standards of known number of microspheres from the same batches, the number of spheres in the various samples and tissues could be calculated. Blood flow (F) was calculated, as described by Rudolph \& Heymann (1967), as $\left(Q_{\text {ref }} \times N_{\text {organ }}\right) / N_{\text {ref }}$, where $Q_{\text {ref }}=$ rate of withdrawal of the reference sample, $N_{\text {organ }}=$ number of spheres present in the organ and $\mathbf{N}_{\text {ref }}=$ number of spheres present in the reference sample. The accuracy and precision of blood flow measurement by the microsphere technique were calculated as described by Buckberg et al. (1971).

Experiment 2. The effect of laparotomy on testicular blood flow was tested. In 6 rats testicular blood flow was measured by use of ${ }^{169} \mathrm{Yb}$-labelled spheres, and, after laparotomy and exposure of the right spermatic vein, by using spheres labelled with ${ }^{46} \mathrm{Sc}$.

\section{Testosterone assay}

Testosterone concentrations in spermatic venous plasma were measured by radioimmunoassay. The antiserum was raised against testosterone-3-oxime-BSA and had a cross-reaction of $40 \%$ with $5 \alpha$-dihydrotestosterone. $\left[1,2,6,7-{ }^{3} \mathrm{H}\right]$ Testosterone (sp. act. $110 \mathrm{Ci} / \mathrm{mmol}$ : New England Nuclear, Boston, Massachusetts, U.S.A.) was purified in the laboratory by paper chromatography (Bush, 1961) and used for assay and recovery reagent. Plasma $(50 \mu \mathrm{l})$ was extracted 3 times with $5 \mathrm{ml}$ diethyl ether. The testosterone antiserum was diluted $1: 30000$ in borate buffer $(0.05 \mathrm{M}, \mathrm{pH} 8.0)$ containing gelatin $(1 \mathrm{mg} / \mathrm{ml})$, human gamma-globulin $(0 \cdot 1 \mathrm{mg} / \mathrm{ml})$ and $1 \cdot 3 \times 10^{-7} \mathrm{Ci}\left[1,2,6,7-{ }^{3} \mathrm{H}\right]$ testosterone $/ \mathrm{ml}$. The antiserum was added to the diethyl ether fraction after evaporation of the solvent. The samples were incubated for $3 \mathrm{~h}$ at $20^{\circ} \mathrm{C}$. Blanks and standard samples of testosterone up to $3 \mathrm{ng}$ were assayed in duplicate together with the experimental samples. Separation of bound and unbound steroid was achieved by using saturated ammonium sulphate. Liquid scintillation counting was performed in polyethylene vials (New England Nuclear) containing $10 \mathrm{ml}$ of a solution of $27.5 \mathrm{~g}$ Permablend (Packard, scintillation grade) dissolved in 5 litres toluene. The testosterone concentrations were determined from the standard curve which was fitted by the equation given by Leclercq, Täljedal \& Wold (1971).

To test the influence of cross-reacting steroids in the assay a paper chromatographic step, as described by Carstensen \& Bäckström (1976) was used $(n=6)$. Since no significant difference in testosterone concentration was obtained in comparison with a direct assay, the experimental samples were assayed without chromatographic separation. Water blank values were close to zero and were therefore not considered in the calculations. The recovery for the extraction of testosterone was $\mathbf{9 2} \cdot 1 \pm 0.84 \%$ and the coefficient of variation for between-assay duplicate samples was $5.7 \%$. The 
validity of the testosterone radioimmunoassay was further tested by adding known amounts of testosterone to charcoal-treated human female plasma: when $0.75,1.0$ and $1.5 \mathrm{ng}$ testosterone were added, the mean recoveries were $0.74,0.97$ and $1.36 \mathrm{ng}$, respectively. The sensitivity of the assay was $0.2 \mathrm{ng} / \mathrm{ml}$.

\section{Results}

The mean \pm s.e.m. concentration of testosterone in spermatic vein plasma in Exp. 1 was $43 \pm 1.9 \mathrm{ng} / \mathrm{ml}$ $(n=17)$.

Table 1. Organ blood flows (mean \pm s.e.m., no. of observations in parentheses) in anaesthetized male rats prepared with right spermatic vein cannulation

\begin{tabular}{lcccccc}
\hline \multicolumn{1}{c}{ Organ } & Right testis & Left testis & $\begin{array}{c}\text { Right } \\
\text { epididymis }\end{array}$ & $\begin{array}{c}\text { Left } \\
\text { epididymis }\end{array}$ & $\begin{array}{c}\text { Ventral } \\
\text { prostate }\end{array}$ & Kidneys \\
\hline $\begin{array}{l}\text { Blood flow } \\
\left(\mathrm{ml} / 100 \mathrm{~g} \mathrm{~min} \text { m }^{-1}\right)\end{array}$ & $\begin{array}{c}6 \cdot 0 \pm 0 \cdot 8^{*} \\
(17)\end{array}$ & $\begin{array}{c}14 \cdot 5 \pm 1 \cdot 8 \\
(17)\end{array}$ & $\begin{array}{c}7 \cdot 8 \pm 1 \cdot 3 \\
(7)\end{array}$ & $\begin{array}{c}9 \cdot 6 \pm 1 \cdot 9 \\
(7)\end{array}$ & $\begin{array}{c}21 \cdot 6 \pm 2 \cdot 6 \\
(14)\end{array}$ & $\begin{array}{c}261 \cdot 0 \pm 25 \cdot 5 \\
(17)\end{array}$ \\
\hline
\end{tabular}

Mean arterial blood pressure during the measurements was $78 \pm 5 \mathrm{mmHg}$.

* Significantly different $(P<0.01$, Wilcoxon's paired $t$ test $)$ from value for left testis.

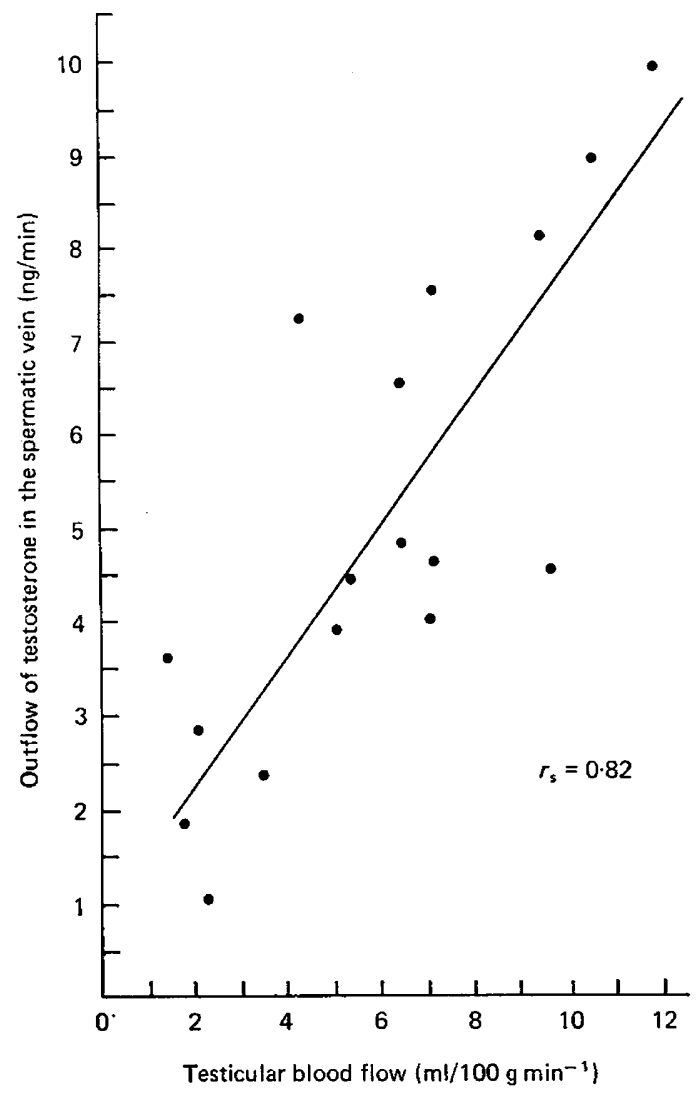

Text-fig. 1. The correlation between testicular blood flow, measured by a radioactive microsphere technique, and the outflow of testosterone in the spermatic venous blood of anaesthetized rats. 
Arterial blood pressure and heart rate were unaffected by the injections of microspheres. The blood flows to various organs are shown in Table 1 . Although the blood flow of the right (cannulated) testis was lower than that of the left (intact) testis, no significant difference was observed between the right and left epididymis. Of the flow in the spermatic vein, $48.5 \pm 3.4$ (s.e.m.) $\%$ represented testicular flow. The relationship between testicular blood flow and outflow of testosterone (ng/min) in the spermatic vein is shown in Text-fig. 1 , and the correlation $\left(r_{\mathrm{s}}=0.82\right)$ was significant $(P<0.005$, Spearman rank correlation coefficient). In Exp. 2, the mean ( \pm s.e.m.) testicular blood flow before laparotomy was $23.7 \pm 4.2 \mathrm{ml} / 100 \mathrm{~g} \mathrm{~min}^{-1}$ and was reduced after laparotomy to $11.6 \pm 1.6 \mathrm{ml} / 100 \mathrm{~g} \mathrm{~min}^{-1}$. The significant reduction $(P<0.05$, Wilcoxon's paired $t$-test) of testicular blood flow $(43.4 \pm 11.2 \%)$ was associated with a reduction in systemic blood pressure of $36 \cdot 8 \pm 5.0 \%$.

\section{Discussion}

In the present study blood flow was probably considerably below physiological levels. Two main factors may account for this. First, blood flow on the side with the spermatic vein cannula was lower than that on the other side. Second, blood flow was significantly reduced by laparotomy and this must also have affected the intact, non-cannulated testis. The reasons for the blood flow reduction, i.e. arterial spasm due to manipulation, increased venous pressure due to cannulation, and decreased systemic arterial pressure due to anaesthesia and laparotomy appear to be unavoidable factors with the present experimental approach. The approach is useful, however, for testicular blood flow measurements provided that the technique correctly reflects the true flow. From the present results, it appears probable that this is the case because the value of $50 \pm 9.8 \%$ measured by direct venous cannulation (Damber \& Janson, 1977) compares well with that of $48 \cdot 5 \pm 3.4 \%$ obtained for the testicular component of the outflow from the spermatic vein in the present study. The values for the blood flow from the 'cannulated' testis may therefore be considered to represent true flow.

The concentration of testosterone in spermatic venous plasma of the rat was in good agreement with the value reported by Knorr, Vanha-Perttula \& Lipsett (1970), but was about $40 \%$ higher than that reported by Free \& Tillson (1973). However, the peripheral concentrations of testosterone found by Free \& Tillson (1973) were only $10-20 \%$ of values obtained in our laboratory (Carstensen, Marklund, Damber, Näsman \& Lindgren, 1976) and those reported by others (Bartke, Steele, Musto \& Caldwell, 1973; Ghanadian, Lewis \& Chisholm, 1975).

The positive correlation between testicular blood flow and outflow of testosterone in the spermatic vein found in this study under in-vivo conditions confirms the tendency observed by Free \& Tillson (1973), and indicates that factors which influence the tonus of the blood vessels of the testis may indirectly affect the synthesis and/or secretion of testosterone. Nguyen Duc Kien, Hamlin \& Gomes (1976) found a parallel reduction of plasma testosterone concentration and testicular blood flow after infusion of prostaglandin F-2 $\alpha$ to rabbits and similar results were obtained for the rat by infusion of prostaglandin E-2 (Free \& Tillson, 1973). One reason why Free \& Tillson (1973) did not obtain the same strong correlation as in the present study may be because their material included conscious and anaesthetized animals. The conscious animals had a lower rate of testosterone secretion than the animals kept under anaesthesia, although there was no difference in testicular blood flow. Testosterone release is a passive phenomenon dependent on rapid diffusion and at high flow rates, like those obtained by Free \& Tillson (1973), testosterone release may be diffusion-limited, while at lower flow rates, as in the present study, the release may be flow-limited.

It is known (Bartke et al., 1973) that plasma testosterone concentrations normally fluctuate during the day with episodes as short as $30 \mathrm{~min}$. Although the $\mathrm{LH}$ value is the main factor responsible for basal plasma testosterone concentrations, it is possible that circulatory variations may contribute to fluctuations in plasma testosterone concentrations.

Work is now in progress with this in-vivo experimental model to investigate the influence of substances such as hormones and vasoactive agents on testicular blood flow and the related testosterone concentrations. 
Financial support for this study was received from The Medical Faculty of Umeå, and The Swedish Medical Research Council (Projects 2148 and 4982). We thank Professor K. Ahrén and Professor H. Carstensen for valuable suggestions; Miss Stina Öberg and Miss Ann Knutsson for skilful technical assistance; and Dr L. Edqvist, Royal Veterinary College, Stockholm, for a generous supply of testosterone antiserum.

\section{References}

Bartke, A., Steele, R.E., Musto, N. \& Caldwell, B.V. (1973) Fluctuations in plasma testosterone levels in adult male rats and mice. Endocrinology 92, 12231227.

Boccabella, A.-V., Salgado, E.D. \& Alger, E.A. (1961) Testicular function and histology following serotonin administration. Endocrinology 71, 827-837.

Buckberg, G.D., Luck, J.C., Payne, B.D., Hoffman, J.I.E., ARChIE, J.P. \& Fixler, D.E. (1971) Some sources of error in measuring regional blood flow with radioactive microspheres. $J$. appl. Physiol. 31, 598-604.

Bush, I.E. (1961) The Chromatography of Steroids, pp. 374-382. Pergamon Press, Oxford.

CARStensen, H. \& BÄCKSTRöM, T. (1976) A paper chromatographic saturation analysis method for measuring estradiol, testosterone and 5-dihydrotestosterone from the same sample. J. Steroid Biochem. 7, 145-149.

Carstensen, H., Marklund, S., Damber, J.-E., NÄSman, B. \& Lindgren, S. (1976) No effect of oxygen in vivo on plasma or testis testosterone in rats and on induction of testicular superoxide dismutase. J. Steroid Biochem. 7, 465-467.

DAMBER, J.-E. \& JANSON, P.O. (1977) Methodological aspects of testicular blood flow measurements in rats. Acta physiol. scand. (in press).

EIK-Nes, K.B. (1964) On the relationship between testicular blood flow and secretion of testosterone in anaesthetized dogs stimulated with human chorionic gonadotrophin. Can. J. Physiol. Pharmacol. 42, 671677.

Free, M.J. \& JAFFe, R.A. (1972a) Dynamics of circulation in the testis of the conscious rat. Am.J.Physiol. 223, 241-248.

Free, M.J. \& JAFFe, R.A. (1972b) Effect of prostaglandins on blood flow and pressure in the conscious rat. Prostaglandins 1, 483-498.

Free, M.J. \& Tillson, S.A. (1973) Secretion rate of testicular steroids in the conscious and halothaneanesthetized rat. Endocrinology 93, 874-879.
Ghanadian, R., Lewis, J.G. \& Chisholm, G.D. (1975) Age related changes of testosterone and dihydrotestosterone in the male rat. Acta endocr., Copenh., Suppl. 199, 423, Abstr.

Johnson, A.D. \& TuRner, P.C. (1972) Early actions of cadmium in the rat and domestic fowl. VI. Testicular and muscle blood flow changes. Comp. Biochem. Physiol. 41, 451-456.

Knorr, D.W., Vanha-Perttula, T. \& Lipsett, M.B. (1970) Structure and function of rat testis through pubescence. Endocrinology 86, 1298-1304.

LeClerCQ, R., TÄlJEDAl, I.-B. \& Wold, S. (1971) Evaluation of radio-isotope data in steroid assays based on competitive protein binding. Clin. chem. Acta 36, 257-259.

LeVin, J., Lloyd, C.W., Lobotsky, J. \& Friedrich, E.H. (1967) The effect of epinephrine on testosterone production. Acta endocr., Copenh. 55, 184-192.

Nguyen Duc Kien, Hamein, R.L. \& Gomes, W.R. (1976) Testosterone secretion rates from rabbit testes after in vivo treatment with $\mathbf{L H}$, prolactin or prostaglandin $F_{2 a}$. Fedn Proc. Fedn Am. Socs exp. Biol. 35, 779.

Rudolph, A.M. \& Heymann, M.A. (1976) The circulation of the fetus in utero; methods for studying distribution of blood flow, cardiac output and organ blood flow. Circ. Res. 21, 163-184.

Saksena, S.K., Safoury, S.E. \& BartKe, A. (1973) Prostaglandins $E_{2}$ and $F_{2 \alpha}$ decrease plasma testosterone levels in male rats. Prostaglandins 4, 235-242.

SetChell, B.P. \& WAITES, G.M.H. (1970) Changes in the permeability of the testicular capillaries and of the 'blood-testis barrier' after injection of cadmium chloride in the rat. $J$. Endocr. 47, 81-86.

Setchell, B.P., Waites, G.M.H. \& ThorburN, G.D. (1966) Blood flow in the testis of the conscious ram measured with Krypton-85; effects of heat, catecholamines, and acetyl choline. Circ. Res. 18, 755765.

Received 15 June 1977 